\title{
CONSERVATION WITH DEVELOPMENT: SHOWCASING LANGKAWI GEOPARK
}

\author{
Halimaton Saadiah Hashim ${ }^{1}$, Sarah Aziz ${ }^{2}$ \\ Institute for Environment and Development (LESTARI) \\ UNIVERSITI KEBANGSAAN MALAYSIA
}

\author{
Rahimah Abdul Aziz ${ }^{3}$ \\ Faculty of Social Sciences and Humanities \\ UNIVERSITI KEBANGSAAN MALAYSIA
}

\begin{abstract}
Debates on whether conservation and development can be integrated have been going on for decades. Economists argue that the economy is the main support of the human race; conservationists argue that without sustainable natural and human resources, economic activities cannot be sustained; humanists argue that culture and history are necessary to sustain a community's identity and continued existence. This article argues that conservation and development can be integrated through sustainable development. Land use planning is identified as the integrating process while sustainable land use development is the manifestation of integrated conservation and development. The geopark concept, developed by the Global Geopark Network (GGN), and endorsed by the United Nations Economic and Cultural Organisation (UNESCO), which promotes conservation, education and sustainable development, is accepted as a concept which conserves natural and cultural heritage while enhancing socio-economic development for the sustainable wellbeing of the local population. Langkawi Geopark is an example of such integration.
\end{abstract}

Keywords: Conservation, landuse development, conservation with development, geopark, Langkawi Geopark

\footnotetext{
${ }^{1}$ Guest Editor, Principal Fellow, Institute for Environment and Development (LESTARI),Universiti Kebangsaan Malaysia, 43600 Bangi, Selangor, Malaysia, e-mail: halima@ukm.my; drhalimaton@ gmail.com

${ }^{2}$ Fellow, Institute for Environment and Development (LESTARI), Universiti Kebangsaan Malaysia, 43600 Bangi, Selangor, Malaysia. e-mail: sarahaziz2000@yahoo.com

${ }^{3}$ Guest Editor, Professor, School of Social, Development and Environmental Studies, Faculty of Social Sciences and Humanities, Universiti Kebangsaan Malaysia, 43600 Bangi, Selangor, Malaysia, e-mail: ikra@ukm.my
} 


\section{INTRODUCTION}

Debates on whether or not environmental protection and conservation should be given a higher priority than development and economic growth have been ongoing for decades. Economists, particularly those in support of weak sustainability, argue that it is economic wellbeing and prosperity that supports environmental protection and conservation, while conservationists, particularly those in support of strong sustainability, argue that environment and natural resources are the basis for sustainable economic growth. A third aspect that makes the debate more complex is cultural heritage - is it as important as environment and economy? Land use planners, when performing strategic land use planning or making decisions for planning and development approvals, have to face these arguments when making trade-offs where they are allowed or possible. Questions therefore arise can there be development without conservation? Are conservation programmes possible if governments do not have enough resources to allocate them among priorities? Is it possible to practise conservation with development?

Conservation is defined as:

"Action taken to prevent decay or dying. It embraces all acts that prolong the life of our cultural and natural heritage, the subject being to present to those who use and look at heritage properties with wonder the artistic and human messages that such properties possess...Conservation must preserve and if possible enhance the messages and values of the properties." (Rosli Hj. Nor 2008:20)

Conservation has a wide scope. However this article only discusses the conservation of heritage as defined by UNESCO and for Malaysia, as defined by the Malaysian National Heritage Act 2005 (Act 645). The Convention Concerning the Protection of the World Cultural and Natural Heritage defined two types of heritage to be protected i.e. cultural and natural heritage. Three categories of 'cultural heritage' are defined in Article 1 of the Convention (UNESCO 1972: 1):

- Monuments: architectural works, works of monumental sculpture and painting, elements or structures of an archaeological nature, inscriptions, cave dwellings and combinations of features, which are of outstanding universal value from the point of view of history, art or science;

- Groups of buildings: groups of separate or connected buildings which, because of their architecture, their homogeneity or their place in the landscape, are of outstanding universal value from the points of view of history, art or science; and

- Sites: works of man or the combined works of nature and man, and areas 
including archaeological sites which are of outstanding universal value from the historical, aesthetic, ethnological or anthropological point of view.

Article 2 of the same Convention also defined three categories of 'natural heritage' as follows:

- Natural features: consisting of physical and biological formations or groups of such formations which are of outstanding universal value from the aesthetic or scientific point of view;

- Geological and physiographical formations: precisely delineated areas which constitute the habitat of threatened species of animals and plants of outstanding universal value from the point of view of science or conservation; and

- Natural sites: precisely delineated natural areas of outstanding universal value from the point of view of science, conservation or natural beauty.

"... The UNESCO terminology has remained unaltered to the present day..." (Yahaya Ahmad 2006: 295). However, the importance of intangible values as part of heritage was emphasised by UNESCO when it adopted a Convention in 2003 (UNESCO, 32nd Session of the General Conference, 2003. Cited by Yahaya Ahmad 2006). The newer convention helped to protect further intangible cultural heritage, which has been defined as "... practices, representations, expressions, knowledge, skills, instruments, objects..." (Article 2). On this Yahaya Ahmad (2006:295) opined that “... while the scope of heritage has broadened to include environment and intangible values, and has received agreements from the international communities the finer terminology of 'heritage' has not been streamlined or standardised, and thus no uniformity exists between countries..."

The Malaysian National Heritage Act 2005 (Act 645) (quoted by Rosli 2008) also basically adopts UNESCO's definition of heritage, with a few variations. The Malaysian Act includes tangible and intangible cultural heritage, natural heritage, underwater cultural heritage and living human treasures as well as treasure trove. Rosli (2008) lists Malaysian tangible cultural heritage to include: cultural heritage sites, historic cities, cultural landscapes, natural sacred sites, movable cultural heritage, museums, underwater cultural heritage, handicrafts, documentary and digital heritage, and cinematographic heritage. Malaysian intangible cultural heritage includes oral traditions, languages, festive events, rites and beliefs, music and songs, performing arts, traditional medicine, literature, culinary tradition and traditional sports and games. While the natural heritage includes national parks and state parks; marine parks; wetlands/RAMSAR sites; mangrove reserves; forest reserves; geological parks; wildlife reserve birds sanctuary; Orang Asli Reserve (Indigenous Peoples Reserves); wildlife rehabilitation centres; and rivers, lakes and seas. 
The above categories of protected areas used to be in isolations. However, this situation soon changed, when conservation was regarded as an active management policy where development and change are not impossible within a broad framework of protecting certain aspects of the heritage (Howard 2003). Various movements, supported by numerous groups and stakeholders, are fighting for this agenda which includes geoheritage conservation, biodiversity conservation and socio-cultural heritage conservation. Protected areas management then have undergone new paradigms. Today most protected areas have taken the holistic approach. They are no longer of single land uses but are of multiple objectives, functions and land uses, serving to protect and conserve geological, biological and cultural heritage while contributing to the socio-economy of the local communities, in a sustainable development scenario. "... Conservation, ultimately, is about promoting good land uses for the benefit of people, future generations, and the land itself..." (Freyfogle 2000: 144).

Nikita Lopoukhine, Chair, IUCN World Commission on Protected Areas, in the 'Foreword' of Lockwood M, Worboy G.L. and Kothari, Ashih (eds) 2006, sums up well the different facets of a protected area in the new paradigm when she describes the 'qualifications' for a protected area manager:

"the manager needs a broad range of skills and personnel attributes to manage effectively. Beyond the core knowledge of an area's natural, cultural and other assets, he or she needs a far deeper understanding of the landscape, both physical and metaphorical, within which protected areas must operate in the 21st century...needs to be part ecologist, historian, economist, sociologist, diplomat, negotiator and marketer to name but a few!" (Lockwood M, Worboy G.L. and Kothari, Ashih (eds) 2006:xxiiii)

Lockwood, Worboy and Kothari (2006) also described the emerging protected area paradigm in which instead of purely protection for preservation, today's protected areas' objectives are combined with social and economic objectives, as well as conservation and recreation ones. They are often set up for scientific, economic and cultural reasons; managed to help meet the need of the local people; the wilderness areas are also regarded as culturally important places; and the objectives are about restoration and rehabilitation, as well as protection, so that lost or eroded values can be recovered.

The new paradigm is in line with the concept of sustainable development, which was popularised by the Brundtland Commission (WCED 1987). Sustainable development is widely accepted as " ... development that meets the needs of the present without compromising the ability of future generations to meet their own needs. It contains within it two key concepts: (1) the concept of 'needs', in particular the essential 
needs of the world's poor, to which over-riding priority should be given; and (2) the idea of limitations imposed by the state of technology and social organization on the environment's ability to meet present and future needs..." (WCED 1987:43). Brundtland's definition means that resources must be sustainably utilised for economic activities to meet present and future generations, within the carrying capacities of each habitat.

\section{CONSERVATION \\ WITH \\ DEVELOPMENT \\ IN \\ SUSTAINABLE DEVELOPMENT}

Aronsun, J. 2006 of Carnegie Mellon has put together several definitions of development - some are quotes while others are his own definitions - in his power-point presentation slides on the website:

i. "Development entails a modern infrastructure (both physical and institutional), and a move away from low value added sectors such as agriculture and natural resource extraction";

ii. "Developed countries usually have economic systems based on continuous, self-sustaining economic growth and high standards of living";

iii. South-oriented definition: "a process which enables human beings to realize their potential, build self-confidence, and lead lives of dignity and fulfilment. It is a process which frees people from fear of want and exploitation. It is a movement away from political, economic, or social oppression. Through development, political independence acquires true significance. And it is a process of growth, a movement essentially springing from within the society that is developing." (The Challenge to the South: Report of the South Commission) 1990;

iv. Human Development: "The basic objective of human development is to enlarge the range of people's choices to make development more democratic and participatory. Choices include: decent wages and employment opportunities, education, healthcare, clean and safe environment, ability to participate in community decision making, and enjoyment of basic human, economic and political freedom. (UNDP Human Development Report, 1991);

v. Development as Freedom: "Development is the process of expanding the freedoms that people enjoy (Sen) Requires removing barriers to freedom: poverty, tyranny and unaccountable government, lack of opportunity, systematic social deprivation, lack of functioning infrastructure, and repression Development depends on people's ability to make good choices in their economic, political, and social lives." and

vi. Gilbert Rist's Definition: "Development consists of a set of practices, sometimes appearing in conflict with one another, which require-for the 
reproduction of society - the general transformation and destruction of the natural environment and of social relations. Its aim is to increase the production of commodities (goods and services) geared, by way of exchange, to effective demand."

The six definitions of development quoted and given by Aronsun (2006) reflect the drive towards wealth and freedom which are mostly associated with development. Very little consideration is made to the health and wellbeing of the environment and to the continuous supply of resources for future generations. A few definitions are even contradictory to the sustainable development concept and therefore are potential threats to natural and cultural resources, part of them regarded as heritage.

Sustainable development is generally regarded as a concept which balances economic development with environmental wealth and social wellbeing. However, since the 1992 Rio Summit, it has often been emphasised as an environmental issue. What is also constraining sustainable development is economic development, which reigns the world today, particularly by developed countries in attaining wealth and by the developing and underdeveloped countries in overcoming poverty and income disparities. In the process, natural resources are fast depleting and there is degradation of the environment, often threatening biodiversities and in turn threaten resources. The definition of 'development' as 'economic growth' being used by the developed countries also hampers the success of sustainable development. Furthermore the definition is also being adopted by the developing countries. Such an approach to 'development', instead of 'sustainable development', cause perils to the environment (e.g. air and water pollution) and exhausting natural resources (oil reserves). Another development which is shifting the perception of sustainable development from environmental issues to social and economic development is the negotiations of WSSD in 2002 in Johannesburg. The shift is driven by the needs of the developing countries and strongly influenced by the Millennium Development Goals (MDG) (Drexhage and Murphy 2010).

In light of the above, since the Rio Summit economic growth has been fed by unprecedented resource and material consumption and related environmental impacts. Large portions of the natural world have been converted for human use, prompting concerns about the ability of the world's natural resource base to sustain such growth. While the world has made some progress on decoupling natural resource extraction from economic growth, the absolute consumption of resources is projected to increase long into the future. This is contradictory to the concept of sustainable development. Impacts are revealed in a number of disturbing trends. Global biodiversity continues to decline, and species in all groups with known trends are, on average, being driven closer to extinction. For example, “...fishery stocks are at the point of collapse, with around 80 percent of the world marine fish stocks for which data is available are 
fully exploited or overexploited (Secretariat of the CBD, 2010:48). The Millennium Ecosystem Assessment reveals that the provision of many critical ecosystem servicessuch as water, biodiversity, fibre, and food - is being compromised due to the impact of human development (Hassan et al., 2005). Scarcity of and competition over freshwater is a growing concern for many regions in the world, with around 50 countries currently facing moderate to severe water stress (WWF, 2008). Climate change will exacerbate water stress and other problems. Current predictions, summarised in the IPCC's 2007 Assessment Report, indicate that the carrying capacity of large parts of the world will be compromised by climate change. Significant political divisions threaten international progress on climate change, yet the window for action to avert the most dangerous effects of global warming is shrinking by the day..." (Drexhage and Murhphy 2010). Therefore, sustainable development has to continue. Conservation and development have to co-exist for economic growth, environmental health and social wellbeing.

To understand the relative importance of conservation and development, OECD suggests that there should be a 'decoupling' of environmental pressures from economic growth, and defines that as the key challenge of sustainable development. It argues that while economic growth was regarded as most important, maintaining functioning ecosystems that can support economic and social development is regarded as very important (in Lafferty 2004:192):

"The interaction between economic growth and the natural environment that supports it lies at the core of sustainable development. Economic growth contributes to higher levels of human wellbeing, and provides the resources to address a range of environmental objectives. Economic growth can however also lead to excessive degradation of environmental and natural resources when incentives to their use are inappropriate and external effects are not internalised. Historically, economic growth has meant transforming much of societies' stocks of natural resources into other forms of capital. Today, maintaining functioning ecosystems that can support economic and social development is recognised as crucial for development to last, especially when no substitutes are available.” (OECD in Lafferty 2004:192).

While it is generally accepted that sustainable development means an interdependency and balance between environmental, economic and social factors, this does not mean that all three aspects must be equally treated. Many assessment of cross-sectoral policy integration of sustainable development indicate that an insistence on 'all or nothing' usually ends up with the latter. In fact Lafferty argues that the general 'environmental' or 'ecological' element of sustainable development is the most fundamental aspect - the one without which the concept loses its distinctiveness (the 'limitation' element); that the notion of 'decoupling' implies a necessary interdependency between environment 
and economics (the 'need' element). To rationalise the above, Lafferty suggests that we "... stipulate a 'three-component' understanding of sustainable development goals, with 'decoupling' understood here as primarily a question of 'integrating' the first two components...” (Lafferty 2004) - see Table 1.

TABLE 1: Basic Goal Components of Sustainable Development

The environmental/ecological component:

Consisting of three major aspects (phases) of normative environmental politics:

\author{
Nature conservation \\ Environmental protection \\ Ecological balance
}

The economic component:

Consisting of the key elements of the Brundtland/UNCED goal of a 'qualitatively different mode of ('sustainable') economic development:

Sustainable production through improved 'eco-efficiency'

Sustainable consumption and lifestyles

The social (equity/poverty) component

Consisting of four equitable distributions of individual life changes to satisfy objectively defined 'basic needs':

National social equity

National generational equity

Global social equity

Global generational equity

Source: Adapted from Lafferty W. M. 2004:193

The general acceptance that conservation can be with development has led to the concept of Integrated Conservation and Development Projects (ICDP) which was introduced by World Wide Fund for Nature in the mid 1980s. The concept is widely practised because it helps to "... reconcile the biodiversity conservation and socioeconomic development interest of multiple stakeholders at local, regional, national and international levels... aimed to reconcile the biodiversity conservation and 
socioeconomic development interests of multiple stakeholders at local, regional, national and international levels..." (Frans and Blomley 2004. Quoted by Garnett et al 2007:1). ICDPs have many different names like 'People-Centered Conservation and Development', 'Eco-development', 'grassroots conservation', 'community-based natural resource management' (CBNRM) and 'community wildlife management' (CWM). ICDPs are normally linked to a protected area.

\section{LANGKAWI GEOPARK FOR CONSERVATION WITH DEVELOPMENT}

This section will showcase Langkawi Geopark as a model for conservation with development. First, it will describe conservation and development in the geopark concept. Secondly it will describe Langkawi Geopark's characteristics which highlight a mixture of conservation and development components and that have symbiotic relations with each other.

\section{GEOPARKS: CONSERVATION WITH DEVELOPMENT}

The Geopark philosophy was first introduced at the Digne Convention in 1991 to promote geological heritage and sustainable local development. In 1997 the Division of Earth Sciences of UNESCO, in response to the 'Declaration of the Rights of the Memory of the Earth', support initiatives in Earth heritage conservation through the creation of a UNESCO Geoparks Programme. This led to the creation of the European Geoparks Network (EGN) and the Chinese National Geoparks Network (CNGN) in 2000 and a year later, in 2001 the EGN was placed under the auspices of UNESCO. In 2004 the Global Geoparks Network (GGN) was formed under the auspices of UNESCO. The network soon spread to Australia, Brazil, Iran, Malaysia, and Vietnam. There was a call for the Geoparks programme to be integrated into the International Geological Correlation Programme (IGCP) and UNESCO's Man and the Biosphere Programme, but was rejected by the Executive Board (Jones C. 2008).

The geopark has its origin from the 1992 United Nations Conference on Environment and Development (UNCED) Summit in Rio de Janeiro. Agenda 21, the strategic action plan for sustainable development, proposed the protection and sustainable development of geological heritage and geodiversity through environment and development. The protection and sustainable development of geological heritage and geodiversity through Geoparks initiatives contribute to the objectives of Agenda 21, namely the Agenda of Science for Environment and Development into the twentyfirst century adopted by UNCED. This was reconfirmed by the World Summit on Sustainable Development 2002 in Johannesburg. The Geoparks initiative adds a new dimension to the 1972 Convention concerning the Protection of the World Cultural and Natural Heritage by highlighting the potential for interaction between socioeconomic and cultural development and conservation of the natural environment. This 
development then led to the current global definition, which is holistic and integrates geo-bio-cultural heritage with socio-economic development of the local communities through the sustainable concept. GGN defines a geopark as:

\begin{abstract}
"A geographical area where geological heritage sites are part of a holistic concept of protection, education and sustainable development. The geopark should take into account the whole geographical setting of the region, and shall not solely include sites of geological significance. The synergy between geodiversity, biodiversity and culture, in addition to both tangible and nontangible heritage are such that non-geological themes must be highlighted as an integral part of each geopark, especially when their importance in relation to landscape and geology can be demonstrated to the visitors. For this reason, it is necessary to also include and highlight sites of ecological, archaelogical, historical and cultural value within each geopark. In many societies, natural, cultural and social history are inextricably linked and cannot be separated (GGN 2010).
\end{abstract}

GGN's geopark definition highlights the synergy between geodiversity, biodiversity and socio-culture which are of high heritage values. Connected to this is social history which identifies the local communities which interact and depend on the environment for a living.

A geopark seeking a Global Geoparks Network (GGN)'s status as a global geopark must abide by the Guidelines and Criteria for National Geoparks Seeking UNESCO's Assistance to Join the Global Geoparks Network (GGN 2010). There are six criteria to comply with: (1) Size and setting, (2) Management and Local Involvement, (3) Economic Development, (4) Education, (5) Protection and Conservation, and (6) The Global Network. The descriptive outline below is a summary from GGN 2010 and can also be taken as a description of an ideal geopark.

\title{
Criteria 1: Size and Setting
}

A Geopark is an area with clearly defined boundaries and an area which is large enough for it to serve local economic and cultural development (particularly through tourism). The geological heritage sites are part of a holistic concept of protection, education and sustainable development. The Geopark should take into account the whole geographical setting of the region, and include sites of biological and sociocultural significance. The Geopark could be identical to, or partly or wholly overlaps with an area already inscribed, (for example, on the World Heritage List or registered as a Biosphere Reserve of the Man and the Biosphere Programme of UNESCO). Geoparks may be located on the territory of more than one country. 


\section{Criteria 2: Management and Local Involvement}

An effective Geopark has an effective management system and programme of implementation. The management body or partnership should have an effective management infrastructure, adequate qualified personnel, and sustainable financial support. A Geopark should have a strong community support and local involvement, supported by local political and community leaders, including necessary financial resources.

\section{Criteria 3: Economic Development}

One of the main strategic objectives of a Geopark is to stimulate economic activity within the framework of sustainable development. Respectful of the environment, the Geopark shall stimulate, the creation of innovative local enterprises, small businesses, cottage industries, initiate high quality training courses and new jobs by generating new sources of revenue (e.g. geo-tourism, geo-products) while protecting the georesources of the Geopark (e.g. encouraging casting instead of the sale of fossils). This provides supplementary income for the local population and shall attract private capital. 'Geo-tourism' is an economic, success-oriented and fast-moving discipline, a new tourist business sector involving strong multidisciplinary cooperation.

\section{Criteria 4: Education}

A Geopark must provide and organise support, tools, and activities to communicate geoscientific knowledge and environmental and cultural concepts to the public. The success of Geopark educational activities depends on the content of tourism programmes, competent staff and logistic support for visitors, and also on the personal contact with the local population, media representatives, and decision-makers. The involvement of local people is of primary importance for the successful establishment and maintenance of a Geopark.

\section{Criteria 5: Protection and Conservation}

The branding of an area as 'geopark' does not necessarily affect the legal status of the land. For legal protection of certain geosites within the geopark, the authorities responsible for the geopark must ensure its protection in accordance with local traditions and legislative obligations. It is the government of the country where the geopark is situated which decides on the level and measures of protection of certain sites or geological outcrops. 


\section{Criteria 6: The Global Network}

The GGN provides a platform of cooperation and exchange between experts and practitioners in geological heritage matters. It allows any participating Geopark to benefit from the experience and knowledge of other members of the Network.

\section{SHOWCASING CONSERVATION AND DEVELOPMENT IN LANGKAWI GEOPARK}

Langkawi is an archipelago located in the northern state of Kedah in the west coast of Malaysia (Map 1). Geographically, Langkawi has one big island (Langkawi Island and 98 other smaller islands), thus giving it the well-known tag of 'Langkawi the 99 Magical Islands' (Map 2). The Langkawi Islands are rich in geological and biological heritage (geo and bio heritage) and socio-cultural heritage from the four main ethnic groups - the Malays, Chinese, Indians and Siamese. The islands are also well known for their history, legends and myths that are very attractive and appealing because they are linked to nature; white sandy beaches as well as black sand beach which are clean and beautiful; outstanding rock formations that are millions of years old (the oldest being more than five hundred million years old); hills and mountains which stand proud and covered with tropical virgin forests; modern and world class tourist resorts and commercial enterprises, farming villages amidst the rice fields; rubber cultivation and fruit orchards; and fishing villages which are located along the coasts of Langkawi, Tuba and Dayang Bunting Islands. The majority of the islands are uninhabited and remain as natural tourist attractions.

MAP 1: The Location of Langkawi Geopark in North-East Peninsular Malaysia

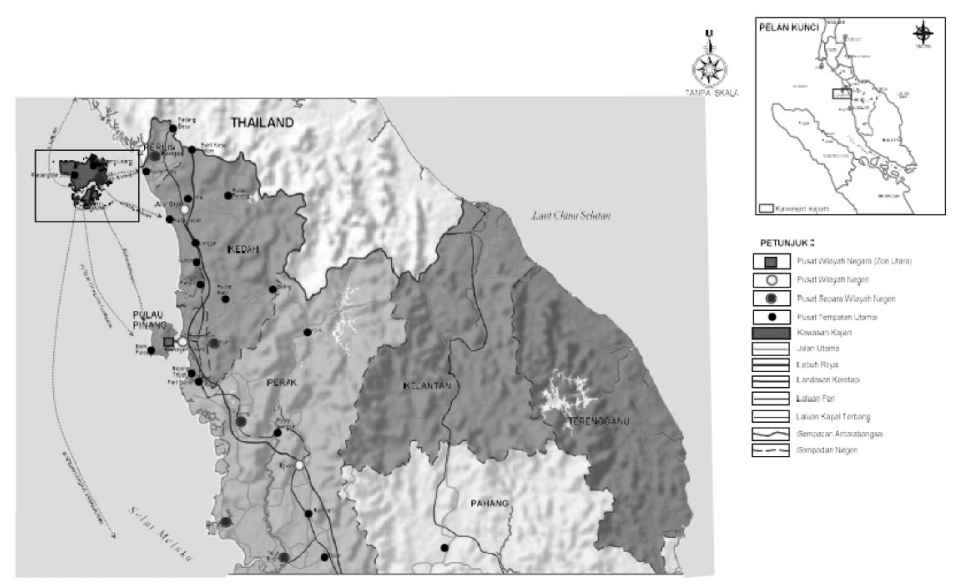

Source: Langkawi District Local Plan 2020 
MAP 2: $\quad$ Langkawi the 99 Magical Islands

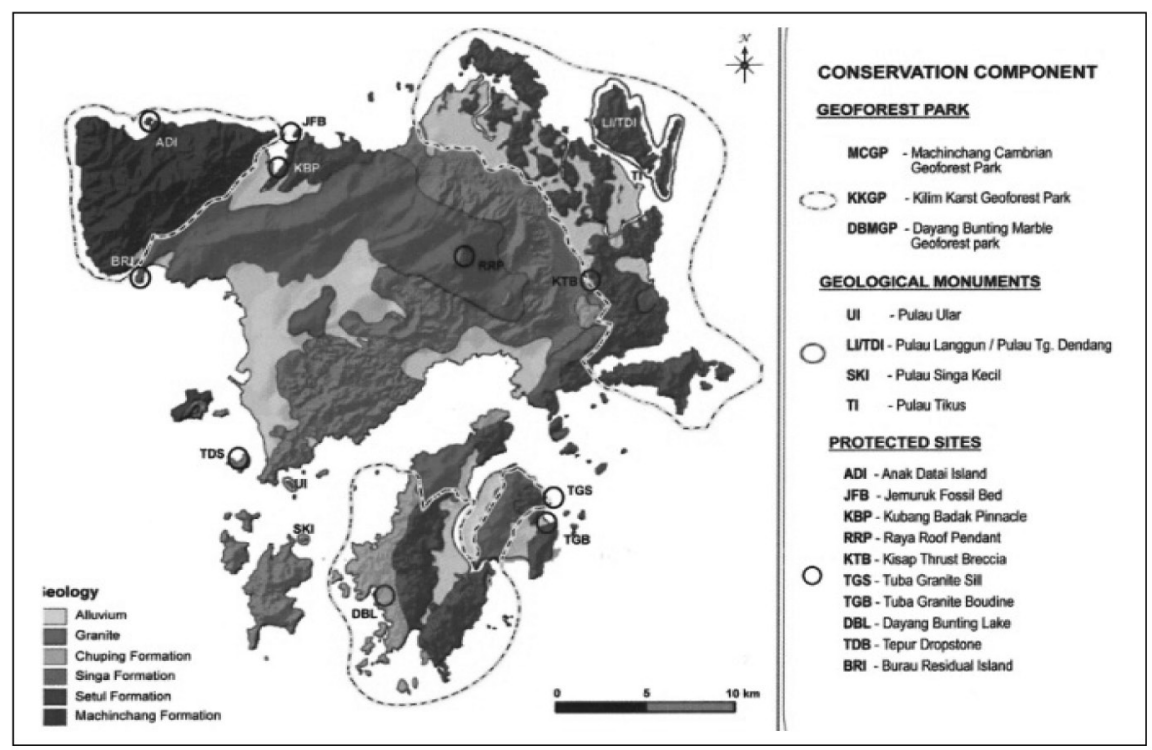

Source: Shafeea Leman et. al. 2007

For a long time Langkawi remained undeveloped and until twenty years ago, had been underdeveloped. However, during the last fifty years she has been known and become popular among nature-loving local and international tourists. The biggest change came when Langkawi experienced a sudden development leap after it was accorded the status as a Tax-Free Island in 1987. Since then there has been rapid development in Langkawi as the new status had enabled the island to enter the international scene. The tourist industry and business activities produced impacts on the physical and socio-economic development. The local population had undergone changes from a traditional life with low income to a semi-modern life with more lucrative income. Infrastructure and modern utilities spread over Langkawi, which had become better known after the Langkawi Declaration on the Environment in 1989 that was signed by Commonwealth Heads of Governments (CHOGM) which met on the island in 1989; the annual Langkawi International Dialogue which was attended by leaders from the South; and LeTour de Langkawi with participation from cyclists the world over.

Langkawi which was 'cursed' to be a padang jarak padang terkukur (in Malay language, meaning a barren field) by Mahsuri the legendary princess, has now been transformed from merely an island of myths and legends, to a tourist island which in the year 2000 was declared Langkawi the Tourism City by the Malaysian government. Today Langkawi has four and five-star hotels, modern roads and infrastructure, which 
bring activities that are able to raise her economy to the level which is relatively similar if not higher than that of mainland Kedah. However, Langkawi is not spared from the negative impacts of rapid development - results of ad hoc development; damaged or polluted environments; non-effective waste management; unsatisfactory infrastructure; modern utilities which have not reached some backward areas; and there are still poor and marginalised populations. Nevertheless, domestic and international tourists are attracted to this idyllic nature and mystical cultural destination which is still pristine in most areas.

In May 2006 Langkawi had another big development shift when it was declared a Geopark by the Global Geopark Network and endorsed by UNESCO in June 2007. The recognition raised Langkawi's status to be the first geopark in Malaysia and South East Asia, and the 52 ${ }^{\text {nd }}$ in the GGN. Langkawi Geopark has geological resources which are over 500 million years old, that is from the Cambrian Age (Shafeea et al 2007) and thus is recognised as an archipelago which has the oldest natural and cultural heritage in South East Asia. Langkawi Geopark was then designed to fulfil the criteria for a global geopark i.e. conserve natural and cultural heritage, education and sustainable development but also with specific objectives of fulfilling LADA's and Malaysia's aspiration (Shafeea et al 2007. The specific objectives are to (1) achieve sustainable development where nature and cultural conservation is given the top priority; (2) multiply tourism products based on the value-added k-tourism; (3) increase the capacities of local communities which are essential in driving its sustainable socioeconomic development; and (4) make Langkawi the nation's leading nature education and research destination among local and international universities' academic and NGO researchers.

Langkawi Geopark's conservation and development activities not only benefit the local population but also provide direct and indirect benefits to Kedah state in which it is located (Kedah is one of the relatively poor states in Malaysia): (1) promoting Kedah to be the pioneer state in the country to have an internationally recognised geoheritage conservation entity; (2) increasing the number of local and foreign tourists to visit Kedah and neighbouring states, particularly Perlis and Penang; (3) increasing abilities to further improve the economy of the neighbouring states; and (4) promoting Kedah state as the leading state in supporting the agenda on sustainable development. Langkawi Geopark is a model example of how protection and conservation of its rich geological, biological and socio-cultural heritage co-exist with socio-economic development of the local population, thus showcasing the sustainable development process. Conservation areas and features, geological monuments and features (geosites and geo-areas), biodiversity, socio-cultural heritage (history, legend and myths) are identified and conserved in line with development needs - socio-economic needs of the local population as well as for national and local revenue through nature-heritage 